\title{
Indian Naval Modernization and its Implications for Pakistan
}

\author{
Saif-ul-Haq*
}

\begin{abstract}
Modernization of armed forces is a way to assert national power beyond geographical boundaries. India envisions itself as a regional hegemon. Indian Ocean Region (IOR) has remained close to the hearts and minds of the Indian statesmen. With the growing volume of sea trade, Indian Navy finds greater share in the national security projection. It has embarked upon an effective modernization plan to upgrade its combat power. This modernization drive is raising grave security concerns for other littoral countries in the region. Since the partition of the Subcontinent, Pakistan has faced the Indian belligerence on all fronts. Conventional asymmetry and actionreaction syndrome largely governs the Indo-Pak Naval relationship as well. Moreover, Indian Maritime Doctrine encourages the Indian Navy to pursue offensive actions to dictate terms of conflict. Such offensive actions are adversely impacting the strategic stability of the region. This paper endeavors to examine the impact of the Indian Naval modernization on Pakistan it suggests some opportunities for Pakistan in view of possible challenges it might have to face.
\end{abstract}

Keywords: Pakistan-India Rivalry, Indian Naval Modernization, National Security, littoral Countries, Indian Maritime Doctrine, Offensive.

\footnotetext{
* The author is M.Sc. in Defense \& Strategic Studies from Quaid-i-Azam University, Islamabad. He holds certifications from Stimson Center USA and the United Nations Office of Disarmament Affairs. His research interests include Nuclear Doctrines, Naval Modernization, Hybrid War and Nuclear Deterrence. He can be contacted at saif61664@gmail.com
}

@ 2021 by the Islamabad Policy Research Institute. IPRI Journal $\square \mathrm{XXI}$ (2): 69-93 https://doi.org/10.31945/iprij.210203 


\section{Saif-ul-Haq}

\section{Introduction}

$\mathrm{I}$ thas been proven scientifically that three-quarters of the earth consists of water and rest is a landmass. Only three per cent of earth's water is on land and rest is the oceans. This fact reiterates the importance of ocean in our lives. Indian Ocean touches Asia to the north, Africa to the west and Australia to the east. It serves as a major conduit for international trade. Economic development of countries in the littoral states of the Indian Ocean is dependent on the Sea Lines of Communications (SLOC). It contains many important strategic choke points like the Strait of Malacca. Littoral states of the Indian Ocean consists of the world's fastest growing economies. It is a rich source of fishing and mineral resources. ${ }^{1}$

Indian Ocean has attracted many great powers around the world. Mahan considered control of seas as an integral factor in projecting the national power. ${ }^{2}$ Controlling strategic trade routes is a way of expressing maritime dominance. While accounting the size and magnitude of the Indian Ocean, no single power can express its dominance over the Indian Ocean Region (IOR). Consequently, states are forming military alliances to achieve maritime dominance in the IOR.

Governance and security in the Indian Ocean are undermined by the naval competition in the region. India is the most populous country in the Indian Ocean Region. It yields great importance for India. Ever since the distant past, continental considerations dominated the Indian strategic thinking. Only recently, India has once again revisited its strategic preferences. SAGAR standing for Security and growth for all in the region expresses the central thinking of India towards the IOR. On the other hand, the United States envisions, "Free and open Indo-Pacific region" It is seeking a strategic partnership with India to offset the Chinese expansion.

\footnotetext{
1 Dinoj K. Upadhyay \& Manoranjan Mishra, "Blue economy: Emerging global trends and India's multilateral cooperation," Maritime Affairs: Journal of the National Maritime Foundation of India (2020)

2 Milan Vego ,"Maritime Strategy and Sea Control Theory and practice" Routledge 2016
} 
Emergence of QUAD is yet another tool employed by the US to keep a check on the Chinese naval presence in IOR. This strategic partnership of India with the US is raising grave security concerns for Pakistan. With its three dimensional force, India wants to achieve maritime dominance over Pakistan. In this pursuit, India has started modernizing its navy. It can operate above, on and under the surface of the oceans for guarding national interests.

\section{Indian Doctrine:}

Doctrine is a set of fundamental principles which guides military forces during various operations. ${ }^{3}$ It is formulated at the strategic level. Doctrine is basically dependent upon the history of war fighting, available technology, state of military knowledge and objectives to which the forces are committed. Whenever military strategy focuses on the pursuit of various strategic goals outlined in the doctrine by the application of military power, it prescribes how available military resources can be employed for the attainment of strategic objectives. Maritime Doctrine outlines the fundamental principles that guide navies during various operations. Maritime strategy entails the application of maritime power for the attainment of strategic objectives enlisted in the maritime doctrine. Indian Navy revisited its maritime doctrine as well as strategy to seek maritime dominance in the IOR.

In order to understand the lately late down Indian maritime doctrine, it is essential to examine its features and modernization of Indian navy. The implications of the Indian naval modernizations and options for Pakistan can be suggested thereon.

This paper attempts to examine the maritime doctrine and modernization of the Indian Navy. In the latter part, an attempt is made to analyze the implications of the Indian Naval modernization and options for Pakistan.

${ }^{3}$ Harald Hoiback," Understanding Military Doctrine” Routledge 2013 


\section{Saif-ul-Haq}

\section{Problem Statement}

Moreover, the strategic stability in South Asia is in danger due to the doctrinal shift and rapid modernization of the Indian Navy. It is acquiring nuclear powered submarines alongside submarine-launched ballistic, as well as cruise missiles. Rapid modernization of the Indian Navy is compelling Pakistan Navy (PN) to enhance it's conventional as well as nuclear capabilities. Understanding the various dimensions of the doctrinal thinking of the modernized Indian Navy will help statesmen as well as academicians to revisit the question of Maritime security in the Indian Ocean. It could be equally detrimental for nuclear no first use policy.

\section{Strategic Dynamics of the Indian Ocean}

Modernization of armed forces is a way to enhance military might for pursuing national strategic objectives in an effective manner. Modernization of the Indian Navy includes building new frigates, surveillance and reconnaissance platforms and submarines. In the literature review, most of the available information was on the strategic dynamics of the Indian Ocean and Indian Naval modernization.

Yogendra Kumar concludes that Sino-US competition in the IOR and convergence of the US and Indian maritime policy are the two principal factors governing the strategic dynamics of the region. ${ }^{4}$ Don McLain Gill contends that China remains wary of the US-Indo alignment in the region, and counters it while pursuing a strategy of containment against India. China's containment strategy has three tiers: trade and investment in the region; soft power diplomacy and the development of strategic ports. ${ }^{5}$ It is suggested that the US designed this construct 'Indo-Pacific' to include the Indian Ocean in its security calculus. ${ }^{6}$

\footnotetext{
4 Yogendra Kumar \& Probal K. Ghosh, "The "Indo" in the "Indo-Pacific"-An Indian View," Naval War College Review (2020)

5 Don McLain Gill, "Between the Elephant and the Dragon: examining the Sino-Indian competition in the Indian Ocean," Journal of the Indian Ocean Region (2020)

6 Sufian-ullah, “Analysing India's Naval Development Strategy," IPRI JOURNAL Winter 2019
} 


\section{Indian Naval Modernization}

Matt Korda points out that after Doklam standoff, Indian threat perception of China has compelled it to expand its nuclear options. In an endeavor to attain Assured Second-Strike Capability against China, India is comprehensively investing on nuclear-powered submarines and submarine-launched ballistic as well as cruise missiles. ${ }^{7}$ Umbreen Javaid contends that the Indian Naval modernization is further widening the conventional asymmetry that exists with Pakistan Navy. Nuclearization of the Arabian Sea and the Bay of Bengal has made nuclear first use highly probable. This aspect is undermining the strategic stability in South Asia. $^{8}$

A comprehensive assessment of the capabilities of the Indian armed forces by IISS (International Institute of Strategic Studies) indicate that the Indian Armed forces envision a triad of space, cyber and special operations, which will complement land, sea and air.

Hence, the reviewed literature suggests that the strategic partnership of the US and India in IOR and subsequent naval modernization, is raising grave security concerns for Pakistan. Since the documentation on the Indian Maritime Doctrine as well as the strategy is restricted, this knowledge gap can be bridged by a close study.

\section{Theoretical framework}

John Mearsheimer's Theory of Offensive Realism provides a comprehensive theoretical framework for understanding the Indian Naval modernization. Mearsheimer contends that states tend to accumulate power to become hegemon. This theory highlights that military power is an essential factor in the projection of national power. States tend to modernize their militaries to increase their national power. Indian Naval

7 Hans M. Kristensen and Matt Korda, "Indian nuclear forces," Bulletin of the Atomic Scientists (2020)

8 Maira Afzazze Saeed and Umbreen Javaid," INDIA'S NAVAL EXPANSION AND STRATEGIC PARTNERSHIP WITH THE US IN THE INDIAN OCEAN REGION: IMPLICATIONS FOR PAKISTAN,” Margalla Papers-2020 (Issue-I) 


\section{Saif-ul-Haq}

modernization can be seen as a manifestation of this idea. Similarly, Kenneth Waltz's theory of balance of power points out that balance of power can be achieved through internal balancing. In order to do so, states enhance their military might.

The research is based on the qualitative method. Descriptive and Predictive data analysis approaches are used while using both primary and secondary data in this research to investigate various aspects of the study.

The study faces limitation in terms of access to official Indian documents and archives in India. There was also a limitation to seek interviews.

\section{Indian Maritime Doctrine}

The word "Maritime" includes everything that is related to the seas. Indian Maritime Doctrine deals with the application of naval power across entire spectrum of conflict. "Indian Maritime Doctrine Indian Navy Naval Strategic Publication 1.1" was published by Integrated Headquarters Ministry of Defense in 2015. It is the national strategic doctrine that guides the Indian Navy's overall strategy. Three levels of thinking exist in the Indian Navy, which includes; Strategic, Operational and Tactical. Maritime doctrine deals with the strategic level. This doctrine outlines the spectrum of conflict, principles of war and concepts of Maritime power as envisioned by the Indian Navy. It also discusses the areas of Maritime interests for the Indian Navy.

\section{Spectrum of Conflict}

Spectrum of conflict covers all the situations in which Navy may be called upon to handle the situation. Conflict spectrum begins with stable peace and ends at a nuclear war. In order to identify a position of conflict in the spectrum, one should focus on ways, means and ends being employed to deal with the situation. Spectrum of conflict includes non-violent as well as violent conflicts.

Violent conflicts are further divided into three categories: Nonconventional hostilities, conventional hostilities and nuclear hostilities. 
Conventional and nuclear hostilities constitute the prime combat zone for the Indian Navy.

\section{Attributes of War}

The purpose of war as envisioned by the Indian Navy remains political as outlined in their grand strategy. This doctrine sheds light on various attributes of war which includes fog of war, friction and fluidity. These attributes of war are instrumental in understanding the dynamics of war. Friction pertains to unanticipated challenges that navies may face in pursuing operations. It may be due to the internal weakness or the enemy's action. Robust command and control structure helps Navies to deal with friction. Fog of war refers to an environment of uncertainty and confusion due to the incomplete and inaccurate flow of information. ${ }^{9}$ Technologies like ISTAR (Intelligence, Surveillance, Target Acquisition and Reconnaissance) ensure speedy and accurate flow of information. Fluidity is related to the dynamism of war. Each stage in a conflict is interconnected to the next. It cannot be observed in isolation. Real challenge for any Navy is to adapt the continuously changing environment. Navies must prepare themselves for a variety of situations.

\section{Concepts of Use of Force}

Indian Maritime Doctrine also discusses various concepts regarding the use of force during the war. These concepts include destruction and attrition, escalation, deterrence and compellence. Destruction refers to a condition when military power is being used to destroy adversary's war fighting capabilities. Attrition is a phenomenon in which progressive destruction of adversary's military forces result in the steady reduction of his war-fighting capabilities. ${ }^{10}$ Compellence is carried out at the tactical level. Compellence entails escalatory punishment. It is being done to ensure acquiescence to the demands being made. Deterrence is a way to

\footnotetext{
9 Strategic thinking, "Fog of War - Strategic Thinking," 2020. http://www.strategy bydesign.org/fog-of-war.

${ }^{10}$ Ministry of Defense Government of India," INDIAN MARITIME DOCTRINE Indian Navy Naval Strategic Publication 1.1," Integrated Headquarters Navy 2015
} 


\section{Saif-ul-Haq}

convince the aggressor that potential losses will outweigh gains in case of any offensive action.

\section{Principles of War}

This doctrine also talks about various principles of war that govern the conduct of military operations. They principles include offensive action, concentration of force, surprise and asymmetry, cooperation and synergy and intelligence. Offensive action is the essence of war-fighting strategy as envisioned by the Indian Navy. To win the war, Indian Navy must control war. Basic idea of any offensive action is to limit the adversary's course of action while preserving your own liberty of action. Any offensive initiative must be seized and retained. It must be used to exploit enemy's vulnerabilities, especially burdening IDA cycle. Pursuing offensive action will let the Indian Navy to dictate the terms of conflict.

Concentration of force is an effective way of achieving operational objectives. During conflict, Indian Navy will concentrate force on certain decisive points in time, space or the information environment to augment its killing power. Concentration of force aims to target enemy's Center of Gravity (COG) with an element of surprise. Basic idea behind the principle of surprise is to hit the enemy at a time, place or manner for which he is unprepared. It gives you tactical advantage, if it is speedy and secret. Surprise must impact adversary's decision-making cycle as well as his counter measures. It is a force-multiplier. Moreover, it gives one an initial edge, but sustain that advantage is the real task. Asymmetry provides navies that continuing advantage. Essence of this principle is to create that favorable imbalance in the conduct of war and then sustain it. Network Centric Operations (NCO) and improved surveillance and reconnaissance platforms are means of ensuring asymmetry.

In order to make any offensive successful, cooperation in the military operations means to compound all war-fighting elements to achieve targets that are difficult otherwise. Conducting joint operations of Land, Air and Naval forces is the need of the hour. Exchange of information and 
mutual support are the key elements of cooperation to encourage synergy which is the outcome of practicing co-operation.

In order to overcome socio-political barriers of time, space and means of conflict in limited conventional wars, synergy is a force multiplier separated by intelligence gathering at all levels. It remains critical for the success of military operations. Officers in Command must have an access to a timely and accurate intelligence reports, which may give you a tactical advantage.

\section{Objectives of the Indian Navy}

Indian Maritime Doctrine chalks out the key objectives of the Indian Navy. Prime objectives of the Indian Navy remains to deter and coerce, ensure decisive military and counter sea-borne threats, deterrence is meant to ward off any military adventurism against any country. It needs coordination/cooperation amongst all the sections of the force.

Indian Navy provides an effective sea-based nuclear deterrent i.e. Assured Second Strike Capability (ASSC). Though India pledges No First Use (NFU) in its Nuclear Doctrine, ${ }^{11}$ it ensures conventional deterrence by denial and punishment by maintaining robust military capability as well as posture to provide effective conventional deterrence. Decisive military victory in times of war is the foremost objective of the Indian Navy and guards long coastal line as well as many important energy infrastructures in the littoral areas such as, sea borne threats. This includes stand-off attacks by missiles, ingress of Special Forces on coast and protecting strategic assets.

\section{Tasks of Indian Navy}

This doctrine also talks about the tasks of the Indian Navy. It includes surveillance, maritime strike, Anti-Submarine Warfare (ASW), Antisurface warfare. It also includes Anti-Air Warfare (AAW), Electronic as

\footnotetext{
${ }^{11}$ Ministry of External Affairs India, "Draft Report of National Security Advisory Board On Indian Nuclear Doctrine". 2020.
} 


\section{Saif-ul-Haq}

well as Information Warfare. Surveillance is the only way of developing Maritime Domain Awareness (MDA). Surveillance is conducted through warships and submarines. Reconnaissance aircrafts, Electronic Counter Measures (ECM), early warning radars and Unmanned Aerial Vehicles (UAV), are also used for surveillance purpose. Maritime strike is an integral facet of the naval power. Similarly, anti-submarine warfare is pivotal in maintaining sea control as well as countering sea denial by adversary. Air Search and Attack Units (ASAU) are tactical formations used for searching and destroying submarines. Submarines can be deployed for destroying submarines.

Action against surface forces is central to achieve sea control or sea denial. Detection of the adversary's force is the first step, which is dependent on the intelligence inputs. After detection, ordnance can be launched, based on targeting data gathered from various sensors. Patrol aircrafts, submarines as well as ASV Helicopters are equipped with AntiShip missiles (AShM). Anti-Air Warfare (AAW) aims to counter enemy aircrafts and air-borne weapons launched from air as well as surface platforms. AAW operations include Air Defense (AD) and Anti-Missile Defense measures. Layers of defense include radars, ship-borne Surface to Air Missile (SAM) systems as well as Electronic Counter Measures (ECM). The main objective of the AAW operations is to neutralize missiles before they reach units.

Information Warfare (IW) aims to secure information advantage against adversary by exploiting its communication networks. Indian Navy will also protect its communication networks. IW includes the use of Operational Security (OPSEC) as well as Psychological Operations (PSYOPS). Electronic Warfare (EW) deals with the electromagnetic spectrum. Indian Navy will use EW to gain advantage over adversary while exploiting its electromagnetic spectrum. EW incudes Electronic Counter Measures (ECM) and Electronic Support Measures (ESM).

Mines are the most effective way of ensuring sea denial. Mines can be deployed in offensive as well as defensive role. Mine Counter Measures 
(MCM) capability is critical for ensuring sea control. MCM vessels must clear mines before the outbreak of hostilities to ensure freedom to use the seas for operations.

\section{Indian Maritime Security Strategy}

"Ensuring Secure Seas: Indian MARITIME Security Strategy" document was published by Integrated Headquarters Ministry of Defense in 2015. ${ }^{12}$ This document points out that key operational activity is to target adversary's sea routes. Interdiction of Sea lines of Communication would be carried out in various areas which include seaports as well as strategic choke points. The Arabian Sea and the Bay of Bengal are the primary areas of interest for the Indian Navy. It will chalk out contingency plans for evolving situations. Factors that impact contingency plans include changes in the strategic environment, shift from stable to unstable deterrence and covert actions. Main lever that will anchor the conventional deterrence is a maritime posture. Maritime posture of the Indian Navy includes force deployment, readiness level and exercise patterns. Preparedness and Presence are the main facets of the Indian Naval combat power. It aspires to have a forward deployment pattern with a ready naval posture.

Indian Navy will curtail the spread of conflict. Escalation management and control are key elements for raising the threshold for nuclear use. Escalation control is achieved by countering adversary's action at all levels. It will gain initiative by counter escalation and then exploit it. It is being done to overcome the gains of adversary's action and will control escalation for its own advantage. Strategy for maritime force development for Indian the Navy consist of three elements: human, conceptual and physical. Conceptual element deals with the doctrinal thinking as well as strategy. Human resource management is a key element for force development. Physical component pertains to military hardware. ${ }^{13}$

\footnotetext{
${ }^{12}$ Ministry of Defense Government of India," Ensuring Secure Seas: Indian MARITIME Security Strategy," Integrated Headquarters Navy 2015.

13 "India's Naval Strategy and Asian Security" Ed. Anit Mukherjee and C. Raja Mohan, Routledge 2016
} 
Saif-ul-Haq

Hence, Indian Maritime Doctrine as well as strategy, focuses on the sea control and denial. Various provisions of Maritime Doctrine and strategy entail offensive action of the Indian Navy. ${ }^{14}$ India Navy will operate on forward lines with an aggressive posture to dictate the terms of conflict.

\section{Indian Naval Modernization}

Naval modernization is a way of upgrading operational capabilities to accommodate changes in the doctrinal thinking. It primarily deals with the material component. Naval modernization includes upgrading armaments, systems of information, including surveillance and intelligence equipment as well as systems for the protection and self-support of troops. Indian Navy is developing its maritime capabilities indigenously as well as with the foreign collaborations. India is a potential buyer of the Russian Naval hardware. It is also acquiring various technologies from the United States. India purchased eight P-8I long range maritime surveillance aircrafts from the US in 2009. This deal amounted worth \$2.1 billion. Rear Admiral Dinesh Tripathi said that the Indian Navy needs 200 warships, as well as 600 aerial assets. Center for Strategic and International Studies (CSIS) assessed maritime capabilities of the Indian Navy in 2016. This report found out that Indian Navy has two operational aircraft careers, 28 principal surface combatants and 14 submarines. This report further pointed out that the Indian Navy had 207 patrol and coastal combatants, 60 amphibious craft, 6 mine warfare/countermeasures vessels and 57 support vessels. ${ }^{15}$ This study will endeavor to find out futuristic prospects of the Indian Naval Modernization while especially focusing on various kinds of ships, submarines, aircrafts, and surveillance and reconnaissance platforms.

\footnotetext{
${ }^{14}$ Sobia Hanif, “Indian Maritime Doctrine: Implications for Pakistan's Security,” NDU Journal 2017

15 Aman Thakker, "A Rising India In The Indian Ocean Needs A Strong Navy" CSIS 2020. https://www.csis.org/npfp/rising-india-indian-ocean-needs-strong-navy.
} 
Indian Naval Modernization and its Implications for Pakistan

\section{Aircraft Carrier}

Indian Navy Chief Admiral Karambir Singh is advocating the acquisition of third aircraft carrier: INS Vishal. He is of the view that in order to counter Peoples Liberation Army Navy in the Indo-pacific, air-borne operations will be an integral facet of the naval combat power. Currently Indian Navy has two aircraft carrier which include INS Vikramaditya and INS Vikrant. In November 2020, INS Vikrant has completed its basin trials in Cochin Shipyard Limited's (CSL) facility in Kochi. It is expected that INS Vikrant will join the Indian Fleet in late 2021 or early 2022. INS Vishal: IAC-2 will be a flat-top carrier with a displacement of 65,000 tonnes. It may have a CATOBAR (Catapult Assisted Take-Off but Arrested Recovery) system. It is anticipated to join the Indian Fleet by 2030.

\section{Destroyers}

Visakhapatnam is a class of destroyers of the Indian Navy which is called as 'Project-15b.' This class comprises of stealth destroyers with guided missiles. Visakhapatnam class of destroyers is under construction at Mazagon Dock limited. Project-15b class of destroyers will comprise of four ships: Visakhapatnam, Mormugao, Imphal and Porbandar. First ship is expected to be commissioned in 2021. This class of destroyers is equipped with Nirbhay, BrahMos and Barak-8 SAM (Surface to Air Missile). Project -18 is another class of destroyers envisioned by the Indian Navy. ${ }^{16}$ This class of destroyers will be equipped with advance weapon systems like electromagnetic railguns, laser-based close-in weapon systems, advanced AESA and PESA radars. This project is presently in its conceptual phase.

\footnotetext{
16 Times of India,"Navy'S 4 Under-Construction Destroyers To Get Lethal Weapons" 2020. https://timesofindia.indiatimes.com/india/navys-4-under-construction-destroyersto-get-lethal-weapons-sensors-package/articleshow/73259960.cms.
} 
Saif-ul-Haq

\section{Frigates}

Nilgiri is a class of frigates which is called as Project-17A. ${ }^{17}$ In this project seven ships will be built at Mazagon Dock and GRSE (Garden Reach Shipbuilders \& Engineers Ltd). This class of frigates will be equipped with Barak-8 and BrahMos. Two ships of this class INS Nilgiri and INS Himgiri are under construction. These ships are expected to join fleet in 2024-25. On average these frigates have a displacement of 6,600 tonnes. Indian Navy is acquiring new advanced Talwar class frigates from Russia under project 11356. These frigates will be useful against submarines as well as adversary's surface ships. The Russian shipyard will deliver two frigates to the Indian Navy by 2022.

\section{Corvettes}

In 2019, Cochin Shipyard Limited (CSL) alongside Garden Reach Shipbuilders \& Engineers Limited (GRSE), signed a contract with the Ministry of Defense (MOD) for eight Anti-Submarine Warfare Shallow Watercraft (ASWSWCs). Future roles assigned to these corvettes will be the surveillance of coastal waters and Anti-submarine Warfare (ASW). These frigates will be stealth. Secondary roles attributed to these corvettes may include engaging adversary's aircrafts and laying mines in the seabed. Next Generation Missile Vessels is a class of anti-surface corvettes envisioned by the Indian Navy. Corvettes in this class will be equipped with anti-land Nirbhay missiles as well as anti-ship BrahMos.

\section{Amphibious Ships}

Budget constraints forced the Indian Navy to revisit its request for four Landing Platform Docks (LPD). Currently, it is planning to formulate a new Request of Proposal for two LPD's with new specifications. As of today, it has only one LPD: INS Jalashwa. While procuring new LPD's, many factors need to be visited. Indian Navy has five large Landing Ship Tanks (LST), 2 medium LSTs as well as eight Landing Craft Utility (LCU) boats. Availability of such force capabilities strengthens the case

\footnotetext{
${ }^{17}$ Naval Technology, "Nilgiri-Class (Project 17A) Frigates", 2020 https://www. navaltechnology.com/projects/nilgiri-class-project-17a-frigates/
} 
for the acquisition of LPDs. LPDs have a twofold use when it comes to combat applications. These LPDs can be used in peace times as well in conflict situations.

\section{Nuclear Submarines}

Arihant is a class of nuclear-powered ballistic missile submarines. This class was built under the Advanced Technology Vessels (ATV) project. Under this project, four such submarines will be built. INS Arihant completed its sea trials and it was commissioned in 2016. INS Arihant is the first submarine of this class. Now a days, INS Arighat is undergoing sea-trials. The other two submarines of this class, code named as S4 and S4*, are under-construction. These submarines will have a much greater displacement and increased number of missile launch tubes than INS Arihant. Furthermore, these submarines will have a powerful pressurized water reactor than its predecessor. By the end of 2025, all four submarines are expected to be commissioned. INS Arihant is equipped with K-4 and K-15 submarine launched ballistic missiles.

Indian Navy is aspiring to build a submarine code named as S5. This submarine will be double in size as compared to INS Arihant having a weight of 13,500 tonnes. It will be equipped with 12 to $16 \mathrm{~K}-6$ submarine launched ballistic missiles. K-6 has the capability of carrying multiple warheads i.e. MIRVS (Multiple Independently Targetable Reentry Vehicles). This project is in its conceptual phase. In 2019, India signed a deal with Russia for acquiring Chakra-3 Akula class submarine. This deal amounted $\$ 3$ billion. Chakra-3 is a nuclear-powered attack submarine. This submarine will be delivered to India by 2025 . Chakra-3 is one of the finest submarines in the world with great stealth capabilities. It can be submerged in water for a considerably longer period.

Under the Project 75 Alpha, Indian government is aspiring to build six new nuclear attack submarines. ${ }^{18}$ This project commenced in 2015. In

\footnotetext{
18 "India Submarine Capabilities, 2020,” Nti.Org. https://www.nti.org/analysis/ articles/india-submarine-capabilities/.
} 


\section{Saif-ul-Haq}

order to overcome an excessive reliance on foreign countries for military hardware, 'Make in India' drive was launched. ${ }^{19}$ These submarines will be designed by the Directorate of Naval Design. Bhabha Atomic Research Center will provide Pressurized Water Reactors (PWR) for these submarines. Mishra Dhatu Nigam Limited is making new hull material for these submarines. New hull material will enable these submarines to dive deeper into water as compared to Arihant class submarines. Initial design phase of this project was completed in February 2020.

\section{Conventional Submarines}

Indian Navy aspires to build INS Vagsheer: a scorpene-class submarine by the end of 2023. It will be designed by a French company and built by Mazagon Dock Limited. This will be an attack submarine which will be powered by diesel and electric transmission. It will have an Air Independent Propulsion (AIP) system. Under the Project-75(I), Indian Navy is aspiring to build six new diesel submarines. These submarines will have AIP system. ${ }^{20}$ This propulsion system will help these submarines to stay in waters for an extended period of time. Furthermore, these submarines will have a vertical launch BrahMos for engaging land and sea targets as well as torpedo tubes for anti-submarine warfare.

\section{Fighter Aircrafts}

Indian Navy has 45 MiG-29K Russian aircrafts that are being operated from INS Vikramaditya. It is facing acute maintenance problems with these Russian aircrafts. Landing on an aircraft carrier is a hard landing. Accounting this problem, Mig-29k aircrafts are becoming costly and operationally troublesome. Furthermore, Indian Navy complains that the Russian technicians are not solving technical problems. It aspires to have more aircraft carriers. Increased number of aircraft carriers demand more aircrafts. With this background, Indian Navy put forward a Request for

\footnotetext{
${ }^{19}$ Ministry of Defense Government of India, "Indian Naval Indigenization Plan (INIP) 2015-2030," Directorate of Indigenization IHQ (2015)

${ }^{20}$ Satu Limaye, "Weighted West, Focused on the Indian Ocean and Cooperating across the Indo-Pacific: The Indian Navy's New Maritime Strategy, Capabilities, and Diplomacy," CNA 2017
} 
Information for 57 Multirole fighter jets. This clearly reflects the rejection of the Russian aircrafts. Potential contenders for the navy tender of multirole fighter jets include the United States' Boeing with its F/A-18E/F Super Hornet; France's Dassault with its Rafale M, Sweden's Saab with its Gripen Maritime and Russia's MiG-29K. These companies assured the Indian Navy that their aircrafts will operate off the ski-jump of INS Vikramaditya. India is also endeavoring to build aircrafts indigenously. DRDO (Defense Research and Development Organization) will build twin-engine aircraft for the Indian Navy that can be operated from deck. It is anticipated that this jet will join the fleet in 2026 .

\section{Helicopters}

Indian Navy is planning to buy 24 Sikorsky MH-60Rs to augment its antisubmarine war fighting capabilities. This deal is worth $\$ 900$ million. It is expected that these helicopters will join the fleet by 2024. In 2017, Indian Navy has also put forward a Request of Information to buy 111 Naval Utility Helicopters (NUH) under strategic partnership model. Under this model, an Indian company collaborates with a foreign company for completing the project. However, Hindustan Aeronautical Limited (HAL) contends that they can cater to the IN requirement indigenously.

\section{Surveillance and Reconnaissance Platforms}

On December 30, 2021 Indian Navy received first of the four Poseidon 8I maritime reconnaissance and anti-submarine warfare aircrafts from the US. This deal was worth $\$ 1.1$ billion. This aircraft is equipped with the latest sensors. It was landed at INS Hansa: a naval base in Goa. Indian Navy already possess a fleet comprising of eight P 8I aircrafts. This aircraft can offer long range surveillance and reconnaissance. Indian Navy has established three dedicated Air Squadrons for operating UAV (Unmanned Aerial Vehicles) for maritime surveillance and reconnaissance platform. These UAV's carry a payload which includes Electro-optic camera and COMINT (Communication Intelligence) equipment. INAS-342 is an air squadron of the Indian Navy which operates two UAV's named as IAI Heron and Searcher Mark II. These two UAV's were bought from Israel Aerospace Industries (IAI). This 


\section{Saif-ul-Haq}

squadron has 12 such UAV's. With an aim to foster communication networks, Indian Navy has requested the Indian Space Research Organization (ISRO) for a new dedicated military satellite: G-SAT 7R. With the acquisition of this satellite, it will be able to establish an effective communication network between various submarines, aircraft careers as well as shore-based assets. Currently Indian Navy is using GSAT 7 satellite.

Ministry of defense and M/s Data Pattern Pvt Ltd signed a contract for nine Precision Approach Radars (PAR) for the Indian Naval Air squadrons. These radars have phased array technology. It is anticipated that these radars will be commissioned by mid-2022. In 2018, Indian Navy and Nova Integrated systems Pvt Ltd signed a deal worth INR 200 crore for procuring a dozen Surface Surveillance Radars (SSR). This deal is a part of 'Make in India' drive. In 2018, Communications, Compatibility, Security Agreement (COMCASA) was signed between the United States and India. As per the provisions of this agreement, US will share high-end encrypted communication and satellite data with the India. India will connect to the US sourced military communication equipment after signing this agreement. Tactical data link will be established between US and the Indian Naval ships. This agreement enables India to procure equipment for dealing with the encrypted information that are suitable with platforms like C-17, C-130 and P-8I.

\section{Naval Exercises}

Naval exercises are conducted with an aim to test the operational preparedness of forces. It is a way to analyze various war-fighting plans and strategies while implementing them in the theatre of war. This study endeavors to analyze few major exercises of the Indian Navy.

In 2017, Western Naval Command (WNC) of the Indian Navy performed a command level operational exercise. It was named as Exercise 'Aarambh. ${ }^{.21}$ Basic aim of this exercise was to evaluate the response time

${ }^{21}$ Ministry of Defense Government of India, “Annual Report 2016-17,” (2017) 
of forces in changing environments from peace to conflict. Furthermore, this exercise focused on observing standard procedures during the conduct of conflict. In August 2017, WNC conducted an operational level wargame titled as 'Exercise PARIKSHAN.' It was a tri-service exercise. Operational and Area commanders as well as teams from the Eastern Naval Command (ENC) also participated. Operational commands of Army and Air-Force also participated in it. Exercise Malabar 2017, was conducted at Chennai and the Bay of Bengal. ${ }^{22}$ Indian Navy alongside US Navy and Japan Maritime Self-Defense Force (JMSDF) participated in it. Exercise Tropex-19 was conducted jointly by the Indian Navy, Army and Air-Force. Indian Coast Guard also participated in it. Amphibious operations were practiced in Andaman and Nicobar Islands. ${ }^{23}$ Sixty ships of the Indian Navy, 12 ships of the Indian Coast Guard and 60 aircrafts participated in this Tri-service war game. Key feature of this exercise was the 'Network Centric Warfare' (NCW). Indian Navy executed NCW with the help of G-SAT 7 satellite that networked 60 ships and 75 aircrafts. INS Chakra, a nuclear submarine also participated in this exercise.

This study has discussed various dimensions of the Indian Naval Modernization comprehensively. Indian Navy is arming at a pace which will increase its combat power manifold. This study finds-out that the Indian Navy is investing heavily in attack submarines, anti-submarine capabilities as well as surface combatants. This modernization drive of the navy will raise grave security concerns in the maritime neighborhood. Various exercises performed by the Indian Navy clearly reflect offensive war-fighting capabilities.

\section{Implications for Pakistan Navy}

Rapid modernization of the Indian Navy coupled with its offensive warfighting capabilities is yielding grave security concerns for the Pakistan Navy. ${ }^{24}$ This study aims to find out the implications of the Indian Naval Modernization for Pakistan Navy. Budget allocated to the armed forces

\footnotetext{
${ }^{22}$ Ministry of Defense Government of India, “Annual Report 2017-18,” (2018)

${ }^{23}$ Ministry of Defense Government of India, “Annual Report 2018-19," (2019)

${ }^{24}$ Asma Sana \& Shaheen Akhtar, ” India's 'Indo-Pacific' Strategy: Emerging Sino-Indian Maritime Competition,” Strategic Studies:40(3), 2020
} 


\section{Saif-ul-Haq}

decides their weapon acquisition and impacts their operational planning as well. A percentage of the Indian and Pakistani Naval budgets, as a portion of total defense budget, is shown in the column chart below.

\section{Column Chart 1:}

Percentage of Naval Budget from total defense budget Vis a Vis PN and IN. ${ }^{25}$

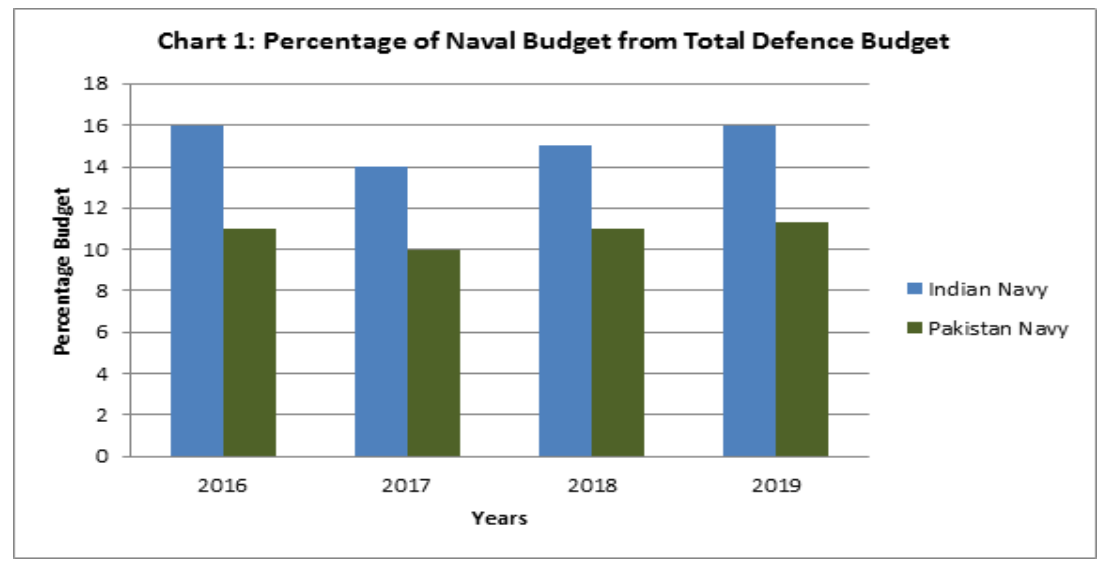

This chart clearly reflects that Pakistan Navy is lagging in terms of budget allocations. On average Indian Navy receives $15 \%$ of the total defense budget, whereas Pakistan Navy receives only $10.85 \%$ of the total defense budget annually. Increased budget allocations for the Indian Navy reiterates the fact that India takes the Indian Ocean as an important tool for national power projection. Pakistan, due to its geography, has been constrained to follow land centric military strategy. Furthermore, Indian obsession with the limited warfare and provocative doctrines like Cold Start and Land warfare doctrine has compelled Pakistan to enhance the military capabilities of its land forces. ${ }^{26}$ Pakistan has a coastal line that is 990km long. It is divided into two parts: Sindh coast (270km) and Makran

25 Laxman Kumar Behera," India's Defence Budget 2020-21" Manohar Parrikar Institute for Defence Studies and Analyses (MP-IDSA) $2020 \mathrm{https} / / /$ idsa.in/issuebrief / indiadef-budget-2020-21-lkbehera-040220

${ }^{26}$ Muhammad Abbas Hasan, "Indian Initiatives for Maritime Dominance: Pakistan's Options and Response,” Islamabad papers: 42, 2019 
Coast $(720 \mathrm{~km})$. Pakistan has an Exclusive Economic Zone (EEZ) of 240,000 sq.km. It is heavily dependent on its Sea Lines of Communications for trade. Port Bin Qasim, Karachi and Gwadar deals with $95 \%$ of the total trade volume. Maritime economy is the future of Pakistan. Pakistan needs to utilize its maritime resources to the fullest. Accounting the expansion of Gwadar port under the CPEC project and establishment of Free Economic Zone, reliance on the sea Lines of Communication has further increased. Pakistan is an important littoral state in IOR. In view of the aforementioned points, it is the need of the hour to revisit the question of Maritime Security for Pakistan. In future, Pakistan Navy will find a greater role in the national power projection. In order to strengthen the Maritime security, the Government of Pakistan must increase the budget allocation for Pakistan Navy.

Since Independence, there exists a conventional asymmetry between Pakistan and the Indian navies. Booming economy of India enables it to acquire latest weapons and technologies. Comparison of naval hardware between Pakistan India is shown in the chart below.

Column Chart 1(A):

Comparison of Naval equipment Vis a Vis PN and IN. ${ }^{27}$

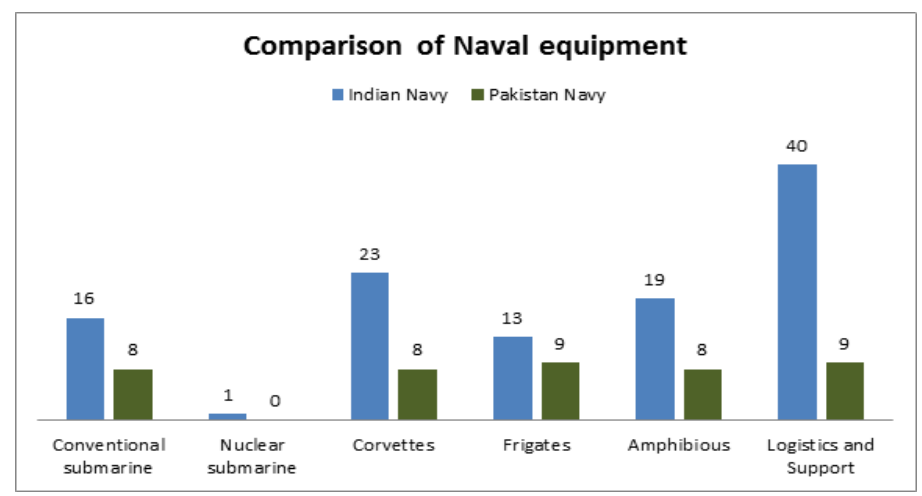

${ }^{27}$ The International Institute of Strategic Studies, "Chapter Six: Asia, The Military Balance," (2020) 


\section{Saif-ul-Haq}

This column chart clearly indicates the conventional asymmetry that exists between both the navies. In order to respond to the future contingencies, Pakistan must augment its combat power.

It must develop a strong industrial base for building naval hardware indigenously. Pakistan Navy must encourage private sector to develop collaboration with the foreign companies. Furthermore, Pakistan must focus on the Transfer of Technologies from friendly navies.

Pakistan has developed a Navy Research and Development Institute (NRDI) in 2019. ${ }^{28}$ This institute has been developed to bring all stakeholders on board to speed up the modernization process of Pakistan Navy. This institute will link industry, navy and academia. Earlier, according to the modernization plan detailed by Admiral Abbasi in 2019, Pakistan Navy will be adding 50 new vessels including 20 major ships. All the great powers of the world are reluctant to share technologies, as well as military hardware with Pakistan. Prime reason of this reluctance resides in the inclination of major powers towards India due to the economic interests.

China and Turkey have remained steadfast in assisting Pakistan Navy to upgrade its fleet. Pakistan and China signed a contract for four frigates. A contract was signed with Turkey for four medium class ships. Under the Hangor submarine project, four submarines will be built in China and four in Pakistan. Furthermore, Pakistan Navy is aspiring to develop hypersonic ship launched anti-ship ballistic missile. Pakistan Navy is developing UAV jammers, directed-energy weapons, underwater sonar surveillance and coastal defense systems. China and Turkey have helped Pakistan to improve its domestic industrial base for indigenously building various kinds of naval vessels.

In order to respond to the growing threats to the maritime security, Pakistan has also pursued new formations. Pakistan Navy transformed the

28 The News, "Pakistan Navy Holds Operational Commands, Industrial Seminar".2020 
traditional destroyer and patrol craft squadrons into three specific Surface Task Groups (STG). These STG's are stationed at Gwadar, Ormara and Karachi. Pakistan Navy operationalized the naval air stations in the west coast for day and night surveillance operations. It has revisited its creek area strategy. It will focus on offensive operations to attain tactical advantage in this area, and has raised Integrated Strike Groups comprising of both Marines and Special Operations Forces (SOF) units.

Pakistan Navy is aspiring to acquire 10 new long-range maritime patrol aircraft (LRMPA) to replace its aging P-3C Orion Aircrafts. Pakistan Navy also inducted JF-17 fighter jets into Minhas squadron. It has inducted Zarb Coastal Defense System which is based on a Chinese antiship cruise missile system. It also inspires to induct anti-ship ballistic missile system for countering aircrafts carrier. Naval Strategic Forces command successfully test-fired submarine launched cruise missile: Babar-3. This enabled Pakistan to complete its nuclear triad. However, it still lacks the possession of nuclear-powered submarine. Effective and assured second strike capability is linked with the acquisition of nuclearpowered submarine.

The term "Strategic Stability" entered the nuclear lexicon during the Cold War era. Strategic stability can be defined in three possible ways: Firstly, it is the absence of the incentive for the nuclear first use (crisis stability) alongside the absence of incentive for building nuclear arsenal (arms race stability). Secondly, it describes the absence of armed conflict between nuclear armed states. Lastly, it talks about a regional security environment in which nuclear armed states enjoy harmonious relations.

Nuclearization of the Arabian Sea has made nuclear use quite probable. Although, India denies Nuclear First Use, but its nuclear doctrine has great flexibility to permit any such action. Menon, National Security Advisor of India, uses a term 'splendid' first strike. Gen. Sunderji also advocated the idea of counterforce preemption. Central idea is to engage all counter-force targets of Pakistan to destroy its nuclear capabilities. Once, this target is achieved, India can easily pursue any limited 


\section{Saif-ul-Haq}

conventional action on land as well as sea. Such Indian endeavors are undermining the strategic stability in South Asia. This counter-force preemption leads to 'First-strike' instability. First strike instability refers to a situation where Pakistan may fire the nukes first in its insecurity, that India will destroy its nuclear capabilities completely. Geographical contiguity shrinks the strategic response time between Pakistan and India. In this backdrop, use of submarines for nuclear first strike is threatening the regional security to the fullest.

Indian Naval modernization is a tool to overcome the deficiencies in force structures to multiply its combat options for efficiently achieving its operational objectives. An acquisition of the nuclear powered submarines and other attack vectors is the validation of aggressive doctrinal thinking of the Indian Navy. Offensive doctrinal thinking of the Indian Navy materialized by the acquisition of required naval hardware, which reiterates grave security concerns for Pakistan Navy, while considering the geographical proximity and historical enmity. In this fashion, Indian Naval modernization is undermining two components of the strategic stability in South Asia: crisis stability and arms race stability.

During the 1965 war as well as 1971 war, Western and Southern Command of the Indian Navy attacked Pakistan. Western command of the Indian Navy is headquartered in Mumbai. It covers the Arabian Sea adjacent to Pakistan. Carrier Battle Group of this Western fleet is composed of an aircraft carrier, frigates, destroyers as well as submarines. Due to geographical proximity, an offensive action of this formation can yield grave consequences for Pakistan. Furthermore, air squadrons of this command pose serious threat to the ports of Karachi and Gwadar. Air squadrons of Southern as well as Western commands, also perform surveillance and reconnaissance. As dictated by the Indian Maritime Doctrine as well as Strategy, any formation of these commands can interdict Pakistani SLOC's for pursuing economic strangulation.

This study has briefly discussed various implications of the Indian Naval modernization for Pakistan Navy. Lt-Gen Talat Masood is of the opinion 
that Pakistan must pursue modernization to deter the Indian Navy. Pakistan Navy must develop effective capabilities with a ready posture to counter maritime threats at all levels. Pakistan pursues a doctrine of Full Spectrum Deterrence (FSD). Pakistan must remain vigilant in ensuring deterrence at the conventional as well as strategic level. It must focus on the acquisition of surface combatants, nuclear submarines, coastal defense systems as well as surveillance and reconnaissance platforms. It must focus on the indigenous industrial production as well.

\section{Conclusion}

Indian Naval modernization reflects the importance of IOR as an instrument of national power projection. US is using India to counterbalance Chinese ambitions in South China Sea. Rapid modernization of the Indian Navy is a source of potential insecurity for other littoral states in the region. Conventional asymmetry between Pakistan and India is further widened by the Indian Naval Modernization. Indian Navy has augmented its combat power. Due to the geographical proximity and historical antagonism, Indian Navy may interdict SLOCs of Pakistan. At the strategic level, there is a great need to revisit the question of Maritime security in Pakistan. Furthermore, Nuclearization of the Arabian Sea has made nuclear 'First-Use' highly probable. Indian Naval Doctrine enlists various provisions that advocate offensive action. Pakistan Navy must pursue an effective modernization drive primarily focusing on surface combatants, coastal defense systems and nuclear submarines. Pakistan must operate on forward lines with combat readiness. Pakistan must encourage its domestic industries to collaborate with the foreign companies for augmenting indigenous manufacturing capacity. China and Turkey have been steadfast in assisting Pakistan for upgrading its naval hardware. However, scope of this co-ordination must be expanded to ensure a rapid naval modernization for Pakistan. 